\title{
Observations on the history and uses of animation occasioned by the exhibition Eyes Lies and Illusions selected from works in the Werner Nekes Collection
}

Sean Cubitt

In memoriam Théâtre le Capitain Bowles de Swavesey

\section{Abstract}

The exhibition Eyes, Lies and Illusions held at the Australian Centre for the Moving Image (ACMI) in Melbourne and the Hayward gallery in London was a selection from the 20,000 optical toys, scientific instruments, antiquarian books and visual entertainments in the collection of Werner Nekes, the German experimental film maker. This essay begins with a consideration of the historical trajectory of belief in the afterlife in relation to 'animation', the imputation of a soul to anything that appeared to move itself. The second section suggests that animation techniques bear witness to the persistence of atavistic beliefs in modernity. The third addresses the proximity of technology and magic in animation, and proposes a more extended use of the term 'animation'.

\section{Keywords}


Eyes, Lies and Illusions, Werner Nekes, pre-cinema, supernatural

\section{Posthumous Anthropology}

Animation is more than a filmic technique. Animating extends from self-activating automata to theme-park animatronics; its history encompasses the arts of making inanimate objects move or appear to move, of making moving items appear where they are not, of ascribing the ability to move and with it the idea of a soul to objects which can not or no longer can move. These thoughts arise while contemplating the wealth of artefacts over a 400 year history in the Werner Nekes collection, 500 items from a total of 20,000 of which (accompanied by a judicious selection of recent works) were presented in the exhibition Eyes Lies and Illusions (at the Australian Centre for the Moving Image, Thursday 2 November 2006 - Sunday 11 February 2007; previously shown at the Hayward Gallery, London in the winter of 2004-5). The sheer historical depth of the collection and display, and its coincidence with the publication of Siegfried Zielinski's Deep Time of the Media (2006) give an occasion for attempting to place animation in this longer trajectory of Western modernity.

Once upon a time, the individual human being stood at the centre of the universe. Between the later Middle Ages and the Counter-Reformation, the modern Western individual emerged from the Great Chain of Being to stand, in perhaps its most heroic moment, on Shakespeare's stage: the unique, unrepeatable, complex unity of an Othello. There was a price to pay: to stand as an indivisible and self-motivating creature required a separation from the world that gave it birth. The greatest minds of Europe from Aquinas to Loyola devoted themselves to understanding the slow parting from God and the attempt to reach back to Him. The terms of the quest gradually changed as the implications of emergent capitalism became apparent: enclosures, urban drift, industrialisation, alienation and the technologisation of everyday life. Today, as it has been for a hundred years or more, the urban world is vast and anonymous, and our movements no 
longer a matter of will and prayer but of statistical probability. For these last hundred years or so, the individual has been an institution in crisis, called upon increasingly to be the bearer of social responsibility and cultural meaning, yet deprived of the capacity to distinguish itself from the mass of other individuals. Today the cult of celebrity and the new genres of reality TV are required to remind us that individuality is still possible. But during that century, from the institutionalisation to the eclipse of individuality, another proof came to rescue the beleaguered self: death, Each one of us dies alone; and that experience proves that we are distinct from any other. Perhaps the formative moment of Western philosophy in the 20th century, Heidegger's ([1927] 1962) Being and Time, proposes that human being is being-towards-death, a sense of destiny that compels us to live in the time we have, compels us to speak because we know that the long silence lies ahead. For our immediate forebears, however, something else intervened between the dead and the living: ectoplasm, séances, table-tapping, hauntings and ghosts. The quasi-material return of the dead proved that some essence, persisting beyond death, must therefore also be essential to the living before their demise. The existence of spirits after death proved the existence of the individual in life. The possibility therefore always remained that the anima, the soul, might return: the possibility of re-animation. In what follows I would like to explore what this might mean for the study of animation.

With each new technological invention, especially in the late 19th and early 20th centuries, science would be called upon to demonstrate the persistence of the afterlife. Edison's marketing of the phonograph on the basis that it would preserve the voices (and implicitly the breath) of lost loved ones (1878), and the employment of the phonograph and later the magnetic tape recorder in creating records of ghostly rustlings and words bear testament to this re-animating effect in the world of sound recording. Science, in its effort to reveal the unseen forces of nature, was to bring to hearing - and through photography, cinematography 
and broadcasting to sight - the unheard and unseen realms of those who had passed over.

Amidst the forest of funerary art in the Cimitière Père La Chaise in Paris stands a stone monument on one side of which, in bas-relief, a crowd gazes upward as a balloon, in construction very like the Montgolfiers', flies up over Paris; on the opposite side, another crowd reels backward from a ghostly apparition. It is the final resting place of Etienne Gaspard Robertson, born Robert, best remembered as the proud populariser of the Phantasmagoria (Levie 1990), that elaborate stage show of smoke and mirrors that, in the wake of the terror, enthralled the citizens of the French Republic. To us there is a quaint mismatch between the ghouls on one side of the tomb and the technological promise on the other. On the one hand, the balloonist's panorama would swiftly be incorporated into panoramic prints and architecture; on the other, the phantasmagoria is a lost art of a quaint superstition. But Robertson boasted its scientific credentials as the debunker of the Catholic illusions of Della Porta and Kircher, a producer of 'scientific effects' (Grau 2007: 147). At the same time, the reception of such new ways of seeing was fundamentally ambivalent. On the one hand, like the supposed reanimating powers of electricity which also formed part of Robertson's shows, there was the scientific demonstration; on the other the affective structures of wonder and horror which Joseph Wright of Derby captured so well in his painting Experiment on a Bird in the Air Pump of 1768 (now in the National Gallery, London), One need only think of Pepper's ghost. a trick with half-silvered mirror to project a living ghost on stage among the actors. Devised by the director of the Regent's Street Polytechnic, a haven of self-improvement for mechanics and artisans which, a decade or two later, would host the first London screening of the Lumière cinématographe, the 'ghost' was both scientific marvel and object of awe.

Cinema itself would be haunted by these animated, automated machines, perhaps most poignantly in Renoir's La Règle du jeu (1939), whose Count is 
perpetually fascinated and fearful of his fairground organs and music-boxes, at once instruments, and so devoid of life, and yet capable of this mysterious ability to produce, by their own devices, the music that has the piano-player lean back in something like horror from the player-piano in the danse macabre sequence. Some kind of dread obtains still as we face our mechanical other, from the false Maria of Metropolis (1927) through the cavernous mind of the Krel in Forbidden Planet (1956), to the face-off that concludes Matrix Revolutions (2003), and now finds a new source of anxious confrontations in the genetic modifications of $X$ Men $(2000,2003,2006)$.

Animation may then be seen not only in terms of inanimate objects magically brought to light, but as the rebellion of things. Without a god to drive them, and in the absence of a human user, self-moving things seemed to have no explanation except mysterious forces, the kind of supernatural forces that had to be imagined entirely anew in an increasingly secular world from the flotsam and jetsam of catholicism and older pagan beliefs. Once Western individualism separated the human from the divine, the body itself became a mystery. No longer moved by God, it was increasingly conceptualised as a motor: powered by food, delivering work (Rabinbach 1990). In rather different ways, Bruce Mazlish (1993) and Giorgio Agamben (2002) address this history as a tale of boundaries. For Augustine, Aquinas and Descartes, the dividing line was the waist: above was human, below animal. After Darwin, the boundary shifted to the neck: the head was speech and rationality: everything else was shared with the beasts. After Freud there was only the face, behind which lay the animal instincts. In a parallel shift, where the ancients saw tools doing the will of their users, in Marx machinery dominated workers, but after Norbert Wiener's (1950) popularisation of cybernetics, the distinctions between humans and machines dissolved, expressed in embedded technologies like pacemakers. With in vitro fertilisation (Habermas 2003), genetic engineering and biocomputing (Thacker 2004), the ambivalence of scientific discovery and magical powers continues. Deriving from 
the question of individuality, the questions of what is human and where the boundaries lie between humanity, nature and technology produce personal and social anxieties. Where do "l" stand, between the mass of humanity, the processes of the natural world, and the increasingly autonomous and incomprehensible machines that surround and inhabit me? These taxonomic issues experienced at the personal level, are also major themes of social and political modernity. The boundary conditions between living and non-living that animate animation are more than entertainments: they address, in public and affective forms, some of the profoundest problems of becoming modern,. The Nekes collection provides a unique site for pursuing this enquiry through the period from the Baroque to the early 20th century.

The ambiguous relation between human, natural and technical raises a further question. If we humans to exist in some special way through the persistence of the soul in a posthumous spirit world, where do the souls of increasingly humanlike animals and machines persist? In titles like Koestler's much-imitated Ghost in the Machine (1967) and Tracey Kidder's classic anthropology of the design and fabrication of a computer, The Soul of a New Machine (1981), the imputation of some kind of life, some kind of essence, to machines mirrors the soul's flight from the exclusivity in which earlier religious and humanistic perspectives had corralled it. If the function of belief in the afterlife became one of distinguishing the individual soul from the crowd in the age of the masses, how did people cope with the dawning sensation that such living essences were no longer the unique preserve of human beings? What processes of accommodation and mystique characterised that discovery of strange congruence? And what do we stand to learn from it today?

\section{Atavism}

Among the Werner Nekes' collection are secret sigils, political satires concealed in innocuous landscapes or disguised in anamorphic smears, double images like 
Wittgenstein's famous duck-rabbit, toy theatres, panoramas, rotoreliefs, tracts and erotica . . . a cornucopia of variety and difference, of items which present themselves as other than they are, that change their aspect, that seem to grow or die in front of your eyes. To restrict this rich culture of disguise and revelation to the status of "pre-cinema" is rather like Gary Larson's memorable cartoon of the family huddled in a semi-circle round an empty corner of the living room, titled "Waiting for the Invention of Television". Their inventors and users had no conception of a teleological goal toward which these toys tended: for them they were ends in themselves, and it is important in the interests of historiographical integrity to treat them in their context, rather than in ours. Toy theatres and shadow puppets might perhaps be read in retrospect as pre-cinematic (the Mandarin term for cinema translates as 'electric shadows'), as both Ceram (1985) and Mannoni (2000) argue. One problem is that the same phenomena can also be read as precursors of quite different media, as they are for example by Grau (2003), for whom similar devices form a pre-history of immersive media, for Ndalianis (2004) of postmodern theme parks, rides and games, and for Stafford and Terpak, for whom they prefigure desktop interactions and CD-ROM. While it is legitimate to place these devices in the past of cinema, it is misleading to try to keep them there to the exclusion of these other histories. Their abiding fascination is about the possibility of playing with them in the present, about the disorienting dislocation we experience when confronting once-familiar, now forgotten, relics of the recent past, about their difference from contemporary media as well as their similarities. They cannot be judged as failed attempts to produce La sortie des usines Lumières (1895). Stripped of such teleology, they can appear to us as doors to the emotional and intellectual life of the past, and for this enquiry, as the concentrated result of thinking through the issue of what is alive and what is not: the problem of animation.

Anima means not only spirit but breath, and not only the breath of living animals but the breath of wind that animates the leaves. That first animation must have 
had the most magical significance for our ancient ancestors as they began the huge, liberating, tragic task of distinguishing phenomena from their causes. How immensely difficult that first step on the road of distinctions, how fraught with futurity: to distinguish the wind from the leaf, the motive from the motion, to see that the one animates the other. It is these formative distinctions, I believe, and the process of distinguishing which they inaugurate and never entirely conclude, which fuels the abiding fascination of optical toys and optical illusions. The very distinction of rational and irrational that underpinned the science-superstition dialectic of Pepper's Ghost is inscribed in the discriminations that would sever the innocent continuity of inhabiting the world that our earliest ancestors - and we ourselves as infants, ontogeny recapitulating phylogeny - undertook in a universe overcrowded with significance but without enough causality to go round.

As Arendt notes of the Greek city-state, 'The distinctive trait of the household sphere was that in it men lived together because they were driven by their wants and needs ... . The realm of the polis, on the contrary, was the sphere of freedom' (Arendt [1958] 1988: 30). The twofold function of the polis was 'to multiply the occasions to win "immortal fame"' and 'to offer a remedy for the futility of action and speech' (Arendt [1958] 1988: 197). Clustering into societies in pursuit of an immortality that the mere work of survival could never guarantee freed the Greeks from the necessity of mere biological existence. That very freedom not only separated them from the green world of nature and natural necessity: it risked making the extraordinary act banal. In Quetelet's 19th century, this mass of individual acts became the basis of a statistical science of population, a calculus of probabilities (Porter 1986, Doane 2002). At the same time, Marx was theorising technology as dead labour, the accumulated skills of our forebears ossified and enslaved in machinery (Marx 1973: 690-711; see Cubitt 2008). It was in this context of humanity alienated in the aggregate mass and in the form of machinery that technology itself, in the form of photography, took to rendering visitations from the dead, and the dead themselves learned 
Morse code to tap tables in imitation of the telegraph (Sconce 2000). Radio and later television would appeal to desires to reach the other side, even as that other moved from realms of the supernatural to battalions of aliens waiting to converse (and for a brief moment in the 1990s to self-generated intelligences in the internet). What should have been the triumph of the social was its demise: democracy brought with it the necessity to manage its mass populations, and in doing so betrayed the social pledge to immortalise individual acts and speech. As these processes of population management begin, with the early ledgers of the Baroque empires of Spain and Portugal, it is as if the soul has been released from its anchorage in the human individual. Soul, anima, is released from the individual in the move to majorities and predictabilities. In the Nekes collection, we find the earliest traces of this autonomous soul, this breath of life capable of inhabiting the otherwise inanimate.

God is not the only one who can imbue with life. To control the wind in the leaves - by tools or imitation - removes the conceptual need for one God and, pluralising godhead, restores the pagan pantheon. The rational monotheism of the Reformation, and the Counter-Reformation's seizing on the same motif of unity in the name of absolute monarchy, would power the Enlightenment's identification of the enemy of reason in superstition, a coded term not only for Catholicism in general, but for the cult of the saints in particular, and beneath that cult the atavistic memory of local gods, spirits of place, multiple and warring tribes of demiurges. The terror acted out by the iconoclasts of Byzantium in the 8th century was not simply in response to the fourth commandment's ban on graven images. It concerned the proliferation of gods so clearly expressed in the other iterations of the commandments in Deuteronomy 5, 6-21 and Exodus 34 12-26. By the time of the crisis of power and its representation in the baroque, it was also a fear of the multiplication of causes beyond the command of a single Will, divine or divinely appointed. The uncanny which so fascinates the earlier pieces exhibited in Eyes Lies thus doubles its address to that afterlife with a 
further posthumous existence: the subreptitious return of dead gods, in their thousands, to animate the rivers, woods and animals that were once their totems.

The ancient spells for good harvests recurred in the legends of John Barleycorn and his avatars; those same spells were both reviled by and recruited for Christianity as anagogical emblems of resurrection, The anxieties associated with this complex repression of pagan thought, and its incomplete forgetting, are captured in miniature in the mythos of the puppet that comes to life. Among Nekes' automata, it is surprising in how many the potential rememoration of lost gods is defused by shaping the automata as children. I want to claim here that animation is not only a film technique: it can describe any attempt to give life to the inanimate. These automata and their latter-day animatronic cousins in movies or in theme parks belong to a history which, as I have argued, is not strictly precinematic because it is also 'pre-' many other things as well, some of which, we can hope lie ahead in the future we do not yet know. The mechanical child is such a figure, especially for addressing that hinterland between the usual means of creating a living child and those used to construct an artificial one. Children figure disproportionately among the early phenakistoscope discs too, not simply because their key market was children (the concept of childhood as a period of harmless recreation was nascent at the time: see Rose 1984), but in order infantilise the magic. Magic, as recall of the old atavisms, was the potent subtext to a history of instrument-making ands scientific experiment that proposed itself as both monotheistic and rationalising. Reconfiguring it as childish helped allay the anxieties they provoked.

Creation might be plural, but its causality belonged to a prime mover who, great clockmaker or world spirit, acted according to self-generated laws, the same laws enumerated by Newton. Many of these 'toys' operate at the margins of Newtonian science, in the spheres of physiological optics and psychology for example, the latter only in the last years of the 20th century stumbling towards scientific status with the aid of neuroscience. Unsurprisingly, many of them also 
feature demons and devils, creatures which, from Baal to Kali, are common derivatives from the gods of conquered peoples. It is thus not only death but what passes for life - the rational construction of common faith, common knowledge and common sense - that is brought back into question among these tricks and amusements. They trivialise as amusements what otherwise they recall: that they are also idols of pagan gods.

The 19th century's industrialisation of meat production and urbanisation gradually severed the old acquaintance with animals. A child playing with toy animals is more free, in these circumstances, to imbue the toy pigs and cows with the child's own attributes. As Melanie Klein ([1929] 1988) observed, such play may also take the form of a narrativisation, a ritual performance, of internal dramas and imagined 'part objects'. If on the one hand this points towards that founding split in the (modern) personality which is the foundation of psychoanalysis, it directs us also towards the tales we tell ourselves when drawing animals, especially those caricatured beasties which populate the animated image, but also for example the rats scurrying across one of Nekes' phenakistoscope discs. Here the relation is double: not only anthropomorphism, but an imagined zoomorphism, a becoming-animal in the act of drawing. The observation, fundamental to Christianity, of the division between human and animal, even when the division is already internal in the form of 'animal passions', of a continuity between human and animal, is as atavistic as the recurrence of polytheism. It was perhaps remiss of God not to have foreseen this development when he set out his fatal strictures against those who made graven images: how much worse a crime to animate them.

\section{Magic}

As with the act of drawing animals, to animate is to reach out through technological means towards natural processes from which the very act of observation has severed us. In this magic there are three terms: the autonomy of 
the observed, the autonomy of the observer, and the autonomy of the line we draw. That third autonomy introduces a particularly structuralist uncanny $\mathrm{n}$ which 'language speaks us'. The autonomy of language, as a rule-governed system, is sufficient for the relationship between a language and its speakers to be a twoway process, one in which speakers change the rules, vocabulary and pronunciation of a language only in restricted ways. Drawing, also a coded practice of selection and arrangement given to the artist as a regulated system, makes as many demands as it enables. This is the burden of William Ivins' (1953) book on the informational content of printed images prior to the invention of photography: that even those which did attempt to derive their content from direct observation from nature were nonetheless in hock to specific codes and practices of drawing particular to each period and region. Drawing is thus not only socially constructed: it produces the designer, as much as the designer produces drawings. The autonomy of the act of drawing is in this sense the prototype of the machinic uncanny: the autonomy of automata, the drawing tools like the Spirograph that draws without a human will to guide it (see Huhtamo 2007). The drawing that 'speaks' the draughtsman is experienced as an influx from the object that is drawn (you imagine yourself a bear as you draw it, just as you imagine its motion as you select a pose to freeze). At the same time the drawing marks itself off from the real bear, but simultaneously evidences the asymptotic approach of subjectivity to its object via the medium of drawing. Even when more complex technologies intervene, such as clockwork in automata, or software in computers, the same rule-governed mediation occurs, at once distancing and approximating, commanding the object and commanded by it, the whole interchange governed by media - clockwork, software, codes of drawing which intervene in and shape the dialogue they perpetuate.

Long understood as an instrumental use of a tool, Gothic and Renaissance practitioners would rarely have thought of a drawing as anything but a working diagram for a competed project: painting, architecture, silverware. It is in the 
period covered by the Nekes collection that the autonomy of the instrument became apparent. The Maillardet automaton in the collection of the Franklin Institute in Philadelphia is a case in point (Penniman 1978): this ephebe, discovered and restored in 1928, when set in motion produced four elaborate drawings and three calligraphic poems. The uncanny derives in part from the automation of the act of drawing, an act which Flusser believed was unique to human beings (Flusser 2002: 110). Flusser however does not mention that what distinguishes human drawing from animal mark-making is the way humans extrapolate the figure from its ground, a process which is only partly completed in the art of the Neolithic. To abstract form from its materiality requires a specific mode of perception and understanding: one that can extract an edge from what it is an edge of; or a shadow from what it falls upon. The common sense belief that drawing is a spontaneous action dependent on specifically human faculties is at odds with the engineers' discovery that it is in fact a rule-governed system. To the extent that this crossover humanises the machine, it also automates the human, so that the uncanny is not exclusive to the device: it inhabits the disturbed understanding of what it is to be human, the unhappy discovery of the constrained, overdetermined and rule governed activities of making meaning.

Standing in front of the exquisite Javanese shadow puppets in the exhibition, how can we know whether past audiences separated the shadow from the puppet, the puppet from the god it represented? The rich colouring on (what to audiences would have been) the invisible faces of shadow puppets suggests even the puppeteers weren't sure. And did Etienne Gaspard Robertson, originator of the phantasmagoria ghost spectacular and pioneer balloonist, distinguish the rationalist enterprise of flight from the apparition of flying skeletons? Like the microscopic anatomy of the flea revealed in Kircher's early lantern slides, the familiar world held untold, unseen mysteries, which in the manner of the old bestiaries might teach the believer of the infinite wisdom and care of the creator (Daston and Park 2001), but might equally propose unseen internal mysteries, a 
micro-subjectivity which would reveal the constant traffic between psyche and soma: not just the death of god but the dissolution of Man.

Siegfried Zielinski's (2006) Deep Time of the Media offers some new ways to consider these artefacts. Zielinski's passion for the hermetic tradition steers clear of the worst excesses of Jungian mysticism, while recalling the line, from Robert Fludd to Vilém Flusser, that stitches a history of media into the intellectual history of the gnostic underground in Western Europe. He reminds us that Newton's dark obsession with alchemy is of a piece with his physics and optics, and that Nicolai Copernicus is as much the heir of Pico della Mirandola's solar worship as he is the ancestor of rationalist astronomy. It is an attractive thought: that right knowing of material science sails perennially close to the perennial philosophy; and that however materialist this history is, it addresses, if only by rejection, the repressed chronotope of the eternal wisdom. While much of the tradition is nonsense, partly perhaps because of its repression, it has historically been the vehicle of a certain utopianism. While this has the negative qualities of wish-fulfillment, it also holds open the possibility of a future, nearer rather than further, in which the evils of the present might be overcome. Like Benjamin's messianic concept of time (Benjamin 2003: 391), the hermetic tradition suggests that any moment in history might be the strait gate through which the future might arrive in all its radical difference. As Adorno argues:

The deepest promise interpretation makes to the mind is perhaps the assurance that it gives that what exists is not the ultimate reality - or perhaps we should say: what exists is not just what it claims to be. We might say then that the negativity of natural history - which always discovers what phenomena used to be, what they have become and, at the same time, what they might have been - retains the possible life of phenomena as opposed to their actual existence. In this sense, the interpretative stance in philosophy is the prototype of a utopian stance towards thought (Adorno 2006: 138)

This utopian quality the hermetic tradition shares with speculative philosophy, 
and in its negative form with the materialism tradition of critical thought exemplified by Adorno. .

Materialism has otherwise, for the most part, eschewed any address to the sacred. This does not mean that materialism fails for lack of theology, nor that the sacred forms some kind of ontological ground which the material world otherwise lacks. Rather, what has been often lacking is an effort to understand that affect which we recognise under the rubric of sacredness, an elevation beyond not only the instinctual but also the intellectual pleasures, a yearning apart from the desire for justice, peace and plenty for all. The word 'sacred' itself is tainted by centuries of mouthing in institutions that have done little for justice, peace or plenty. Critical thinking requires either a different term, or an analysis of how the term has come to present itself as ontology and as immanence. Zielinski quite properly calls this tradition he investigates, which matches closely the interests of Nekes' collection, 'magic'. It is hard nowadays not to recall Arthur C Clarke's dictum that 'Any sufficiently advanced technology is indistinguishable from magic'. What neither Clarke nor Zielinski note is the curiously braided destinies of magic and familiarity. As Don Inde (1990) observes, technologies that at the moment of their invention can appear magical can, with widespread adoption, become 'embedded' and transparent, just as signs written in one's native language are transparent. Embedded technologies like television, once marvelous, become the invisible vehicles of messages whose mediation we scarcely notice (until something goes wrong). The braiding of magic and the mundane occurs when familiarity breeds contentment. Critical studies of technology seeking to induce a sense of the strangeness of their objects need to be alert to both the poetic affordances of analogy and its capacity for mystification. But mystification is as much a result of the embedding of technologies invisibly into the fabric of the everyday as it is of the sleight of hand that announces itself as such. Magic in these latter circumstances is a means towards revealing the utopian capabilities of our present machinery, and of recognising - bringing back to mind freshly - 
rather than mystifying the marvels latent in our most familiar machines.

The devices in the Nekes collection provide an opportunity to do this, specifically to reconsider and bring newly to mind the inferences of the now familiar properties of animated cinema. A distinction might for example be drawn between images which are set in motion, and images which require some kind of motion on the viewer's part. The second was largely left behind in the development of motion pictures (though see Fielding 1970), but returns in theme park rides and, according to Norman Klein (2004) has once again become central to architecture and architectural experience. But we are talking here of much smaller entities, things which can be changed by a small gesture - flicker books, anamorphic images, or images which appear differently or animate when seen from different angles. These are clearly not protocinematic devices, but of some other order. It is in some sense their rarity in contemporary visual culture that makes them interesting. In Eyes, Lies and Illusions, the commonest forms of anamorphosis are puddles of colour with little or no discernible form until they are viewed with the aid of a cylindrical or conical mirror. That some of the resultant images are pornographic and others seditious is scarcely surprising. Hiding is not only a tactic of the weak, but a delight in itself, especially hiding in the plain light of day, like Poe's Purloined Letter. In several exemplars the 'true' image revealed in the mirror is the sexual act. In Lacanian terms, the unmaking of the sex act in the puddle of colours is evidence of the impossibility of the sexual relation (Lacan 1975: 6-7): since what I desire is my own pleasure, I cannot relate to you through sex. The dissimulation is then a double one, hiding the presence of the image in order to disguise the absence it depicts. The extended usage of animation in this context includes not simply applying life to something inanimate, but summoning into being an image and its absence that constantly flicker into and out of existence.

A second type of image which requires a reorientation on the part of the spectator is the reversible image, an example of which appears on the poster for 
both the $\mathrm{ACMI}$ and Hayward presentations of the show,. A memento mori by Giuseppe of about 1700, the image shows a bearded Turk who, when viewed upside down, becomes a death's head: his turban a scarf, and his flowing beard a wig whose curls evoke the fires of Hell. The most technically admirable conversion concerns the eyes, kindly and wise in the Turk, piercing and demented in the death's head. The artist uses the normative rules of engraving workshops, but separates them as elements from the system in which they are supposed to be articulated, firstly to allow them a double purpose, but secondly, in order to achieve the first goal, to sever the elements (crosshatchings for example) from their instrumental position in the grammar of the image. The effect comes close to that noted by Kittler (1999) of the invention of the typewriter: its separation of letters from one another, allowing them a freedom they had never possessed before. Once signifiers are removed from the systematic differentiations guaranteed by the conventions that govern them, however, they stand to lose the meanings which the system exists to enable. The typewriter allows letters to escape their function as writing, to become design elements, to float free of language, but also to become merely decorative. The risk of meaninglessness haunts mediation. Every mechanisation and automation from printing to word processing risks losing the systemic structures and intentional formations on which meaning depends. This seems to be happening with the marks making up Giuseppe's reversible heads. The artist has carefully anchored the doubled images to mottos, and shaped them according to popular emblematic codes. But the innovation involved in the reversal trick requires graphical elements in each variant view which are strictly speaking without meaning. The death's head's teeth and nostril pits form a kind of diadem when looking at the Turk, but it is unconvincing, because the marks composing it do not match the graphical language of the portrait elements. Likewise the Turk's lips which form form the crown of the death's head's wig become inexplicable in style and reference. These inexplicable residues seem to articulate the uncanny of the subject with its execution, the autonomy of the medium intervenes yet again into 
the processes by which images animate.

A similar autonomy of graphical language is characteristic of the early Felix the Cat animations (Canemaker 1991: 36), and in the long history of stop-motion animation of household objects from Blackton and Porter (Musser 1991: 317-20) and Cohl (Crafton 1993: 141-2) to the Brothers Quay. In part, the latter's strangeness is due to the familiarity of the things that come to life. But it is also a function of three animating powers: of the objects themselves, of the viewing subjects, and of the technical media deployed in their animation. The line in Felix, the scissors in the Quays, can trace lineages back to the autonomous marks deployed by Giuseppe, an autonomy which returns as uncanny, because it sits on the borderline between the known and the unknowable, or more precisely between the loss of meaning through an excess of structure and familiarity, and the meaninglessness of signification without a system. The uncanny automata, the motif of death, the supernatural and the afterlife, the images that flicker between being and non-being: these are additions to the cinematic, additions which spill out into robot-automated factories, the frenzy of archiving that characterises blogging, family albums and the genealogy craze, the dislocation we experience when we know we are under surveillance in malls and airports. As in Metropolis, we do not know which to fear most: the self-moving machine, or the threat that we might be driven by a will not our own. The extended usage of animation suggested by the Nekes collection concerns not only the archeology but the present of social anxieties. Throughout the histories traced in the collection, there echoes the tragedy of an entire belief system trampled underfoot, but endlessly recurring in new metamorphoses: in disguises, as demons presented as moral lessons which nonetheless fascinate for their own autonomy from the regime of good, even as they are deployed to uphold it. Indeed, the very turn to metamorphosis seems to be the revenge of a repressed paganism, a magic of perpetual change, danger and risk opposed to the dominance of right reason and a unified common sense. The machinery of 
wonder archived by Nekes retains into the era of total surveillance its challenge of perpetual upset, strange emergences, and fused yet doubled, and as a result endlessly multiplied, animations.

\section{REFERENCES}

Agamben, Giorgio (2002), The Open: Man and Animal, trans Kevin Attell.

Stanford: Stanford University Press.

Arendt, Hannah (1998 [1958]), The Human Condition, 2nd edn. Chicago:

University of Chicago Press.

Benjamin, Walter (2003), 'On the Concept of History' in Selected Writings, vol 4, 1938-1940, ed Howard Eiland and Michael W Jennings. Cambridge MA: Bellknap Press / Harvard University Press. 389-400.

Canemaker, John (1991), Felix: The Twisted Tale of the World's Most Famous

Cat. New York : Da Capo Press.

Crafton, Donald (1990), Emile Cohl, Caricature and Film. Princeton: Princeton University Press,.

Cubitt, Sean (2008), 'Virtual Dialectics and Technological Aesthetics', $\underline{\text { Cultural }}$

Politics, Summer, forthcoming.

Ceram, C.W. (1965), Archeology of the Cinema. New York: Harcourt, Brace \& World.

Daston, Lorraine and Katherine Park (2001), Wonders and the Order of Nature 1150-1750. New York: Zone Books.

Doane, Mary Anne (2002), The Emergence of Cinematic Time: Modernity,

Contingency, The Archive. CambridgeMA: Harvard University Press.

Edison, Thomas (1878), North American Review, June 1878, cited in The History of the Edison Cylinder Phonograph, American Memory Project, Library of Congress, http://memory.loc.gov/ammem/edhtml/edcyldr.html, retrieved 15 October 2007. 
Fielding, Raymond (1970), 'Hale's Tours: Ultrarealism in the Pre-1910 Motion Picture' in Cinema Journal, Vol. 10, No. 1 (Autumn), pp. 34-47

Flusser, Vilém (2002), Writings, ed Andreas Strohl, trans Erik Eisel. Minneapolis: University of Minnesota Press.

Grau, Oliver (2003), Virtual Art: From Illusion to Immersion. Cambridge MA: MIT Press.

Grau, Oliver (2007), 'Remember the Phantasmagoria! Illusion Politics of the Eighteenth Century and its Multimedial Afterlife' in Grau, Oliver (ed) (2007), Media Art Histories. Cambridge MA: MIT Press. 137-161. Habermas, Jürgen (2003), The Future of Human Nature, trans William Rehg, Max Pensky and Hella Beister. Cambridge: Polity.

Heidegger, Martin (1962), Being and Time, trans John Macquarrie and Edward Robinson. Oxford: Basil Blackwell.

Huhtamo, Erkki (2007) 'The Urban Spirograph, or an Archaeology of a Loser', paper presented at the FIAF Congress 2007. Tokyo: National Film Center. Ihde, Don (1990), Technology and the Lifeworld: From Garden to Earth.

Bloomington: Indiana University Press.

Ivins, William M Jnr (1953), Prints and Visual Communication. Cambridge MA: MIT Press.

Kidder, Tracy (1981), The Soul of a New Machine. Harmondsworth: Penguin.

Kittler, Friedrich A (1999), Gramophone, Film, Typewriter, trans and intro Geoffrey Winthrop-Young and Michael Wutz. Stanford: Stanford University Press.

Klein, Melanie (1988), 'Personification in the Play of Children (1929)' in Love, Guilt and Reparation ad Other Works 1921-1945. London: Virago,, 199209.

Klein, Norman M (2004), The Vatican to Vegas: A History of Special Effects. New York: The New Press.

Koestler, Arthur (1967), The Ghost in the Machine. London: Hutchinson. Lacan, Jacques (1975), Le Séminaire, livre XX, Encore. Paris: Seuil,. 
Levie, Françoise (1990), Etienne-Gaspard Robertson: La vie d'un fantasmagore. Bruxelles: Le Préambule.

Mannoni, Laurent (2000), The Great Art of Light and Shadow: Archaeology of the Cinema. Exeter: University of Exeter Press.

Marx, Karl (1973), Grundrisse, trans Martin Nicolaus. London: Penguin/New Left Books.

Mazlish, Bruce (1993), The Fourth Discontinuity: The Co-Evolution of Humans and Machines. New Haven: Yale University Press

Musser, Charles (1991), Before the Nickelodeon: Edwin S Porter and the Edison Manufacturing Company. Berkeley: California University Press.

Ndalianis, Angela (2004), Neo-Baroque Aesthetics and Contemporary Entertainment. Cambridge MA: MIT Press.

Penniman, Charles F. (1978), “Philadelphia's 179 Year Old Android.” BYTE Publications, Aug: 90-94.

Porter, Theodore M (1985), The Rise of Statistical Thinking 1820-1900. Princeton: Princeton University Press.

Rabinbach, Anson (1990), The Human Motor: Energy, Fatigue and the Origins of Modernity. New York: Basic Books.

Rose, Jacqueline (1984), The Case of Peter Pan or The Impossibility of Children's Fiction. London: Macmillan.

Scholem, Gershom (ed) (1989), The Correspondance of Walter Benjamin and Gershom Scholem 1932-1940, trans Gary Smith and André Lefevre. New York: Schocken Books.

Sconce, Jeffrey (2000), Haunted Media: Electronic Presence from Telegraphy to Television. Durham NC: Duke University Press.

Stafford, Barbara Maria and Frances Terpak (2001), Devices of Wonder: From the World in a Box to Images on a Screen, Getty Research Institute, Los Angeles.

Thacker, Eugene (2004), Biomedia. Minneapolis: University of Minnesota Press. Wiener, Norbert (1950), The Human Use of Human Beings: Cybernetics and 
Society. London: Free Association Books.

Zielinski, Siegfried (2006), Deep Time of the Media: Toward and Archaeology of Hearing and Seeing by Technical Means. Cambridge MA: MIT Press.

\section{FILMOGRAPHY}

Forbidden Planet, 1956 , Fred McLeod Wilcox, MGM, US, 99 mins.

Matrix Revolutions, 2003, The Wachowski Brothers, Village Roadshow, Warner Bros, / NPV Entertainment / Silver Pictures, US, 124 mins.

Metropolis, 1927, Fritz Lang, UFA, Germany, 153 mins.

La Règle du jeu, 1939, Jean Renoir, Filmes de la Pleîade, France, 110 mins.

X-Men 1.5, Bryan Singer, 2000/2003, 20th Century Fox/Marvel

Entertainment/The Donners' Company/Bad Hat Harry, 100 mins.

$X$-Men 2, Bryan Singer, 2003, 20th Century Fox/Marvel Entertainment/The

Donners' Company/Bad Hat Harry, 128 mins.

X-Men: The Last Stand, 2006, Brett ratner, 20th century Fox / Donners Company

/ Marvel Entertainment / Dune Entertainment / Ingenious Film Partners /

Major Studio Partners / THINKFilm / X3 Canada Productions / X3US

Productions / XM3 Service,, 99 mins.

Observations on the history and uses of animation occasioned by the exhibition Eyes Lies and Illusions selected from works in the Werner Nekes Collection Sean Cubitt

\section{Author Note}

Sean Cubitt (scubitt@unimelb.edu.au) is Director of the Program in Media and Communications at the University of Melbourne. Among his publications are EcoMedia (Rodopi 2005), The Cinema Effect (MIT 2004) and Digital Aesthetics (Sage 1998). He is a member of the editorial board of Animation: An Interdisciplinary Journal. 


\section{University Library}

\section{- M M I N E R VA \\ A gateway to Melbourne's research publications}

Minerva Access is the Institutional Repository of The University of Melbourne

Author/s:

CUBITT, SEAN

Title:

Observations on the history and uses of animation occasioned by the exhibition Eyes Lies and Illusions selected from works in the Werner Nekes Collection

Date:

2008

Citation:

Cubitt, S. (2008). Observations on the history and uses of animation occasioned by the exhibition Eyes Lies and Illusions selected from works in the Werner Nekes Collection. Animation: an interdisciplinary journal, March, 3(1), 49-65.

Publication Status:

Published

Persistent Link:

http://hdl.handle.net/11343/35080 